\title{
, Zeolite Structures Loading with an Anticancer Compound As Drug 2Delivery Systems
}

\author{
${ }_{3}$ Ricardo Amorim, ${ }^{\dagger}$ Natália Vilaça, ${ }^{\ddagger}$ Olga Martinho, ${ }^{\dagger}$ Rui M. Reis, ${ }^{\dagger}$, Mariana Sardo, ${ }^{\#}$ João Rocha, ${ }^{\#}$ \\ ${ }_{4}$ António M. Fonseca, ${ }^{\dagger}$ Fátima Baltazar, ${ }^{* \dagger}$ and Isabel C. Neves, ${ }^{*+}$ \\ $5{ }^{\ddagger}$ Center of Chemistry, Chemistry Department, University of Minho, Campus de Gualtar, 4710-057 Braga, Portugal \\ $6{ }^{\dagger}$ Life and Health Sciences Research Institute (ICVS), School of Health Sciences/ICVS/3B's - PT Government Associate Laboratory, \\ 7 University of Minho, Campus de Gualtar, 4710-057 Braga/Guimarães, Portugal \\ $8{ }^{\S}$ Molecular Oncology Research Center, Barretos Cancer Hospital, Barretos, São Paulo, Brazil \\ $9{ }^{\#}$ CICECO - Chemistry Department, University of Aveiro, Campus de Santiago, 3810-193 Aveiro, Portugal
}

10 ABSTRACT: Two different structures of zeolites, faujasite (FAU) 11 and Linde type A (LTA), were studied to investigate their suitability 12 for drug delivery systems (DDS). The zeolites in the sodium form 13 ( $\mathrm{NaY}$ and $\mathrm{NaA}$ ) were used as hosts for encapsulation of $\alpha$-cyano-414 hydroxycinnamic acid (CHC). CHC, an experimental anticancer 15 drug, was encapsulated in both zeolites by diffusion in liquid phase. 16 These new drug delivery systems, CHC@zeolite, were characterized 17 by spectroscopic techniques (FTIR, ${ }^{1} \mathrm{H} \mathrm{NMR},{ }^{13} \mathrm{C}$ and ${ }^{27} \mathrm{Al}$ solid18 state MAS NMR, and UV-vis), chemical analysis, powder X-ray 19 diffraction (XRD) and scanning electron microscopy (SEM). The 20 effect of the zeolites and CHC@zeolite drug deliveries on HCT-15 21 human colon carcinoma cell line viability was evaluated. Both 22 zeolites alone revealed no toxicity to HCT-15 cancer cells. Importantly, CHC@zeolite exhibit an inhibition of cell viability up to 23 585-fold, when compared to the non-encapsulated drug. These results indicate the potential of the zeolites for drug loading and 24 delivery into cancer cells to induce cell death.

\section{INTRODUCTION}

26 Several inorganic materials are being explored as drug carriers 27 opening new possibilities for biomedical applications. ${ }^{1}$ Due to 28 their biological properties and stability in biological environ29 ments, zeolites have been recently considered for medical 30 use. $^{2,3}$ Zeolites are solid inorganic crystalline materials 31 comprised of silicon, aluminum, and oxygen in the three32 dimensional structure and the building blocks become arranged 33 in a periodic way to form channels and cages on a nano- and 34 subnanometer scale of strictly regular dimensions, named 35 micropores. 4

36 There are numerous examples of biomedical applications of 37 zeolites reported in the literature including the enrichment and 38 identification of low abundance peptides/proteins, ${ }^{5}$ the 39 immobilization of enzymes for biosensing, ${ }^{6}$ for processes in 40 magnetic resonance imaging, ${ }^{6-10}$ in wound treatment, ${ }^{11}$ and as 41 drug delivery systems (DDS). ${ }^{12-16}$ In DDS, the zeolitic 42 structures and drugs could be simultaneously administrated to 43 a patient without loss of the individual pharmacological effect of 44 each product. ${ }^{17-20}$ However, relatively fewer studies have been 45 reported exploring the potential of zeolites as DDS for cancer 46 applications. The latest experimental studies, based on the 47 results obtained in various tumor cells and in tumor bearing 48 animals, have shown that zeolites can be successfully applied as 49 adjuvants in anticancer therapy. ${ }^{21}$ In this context, we have previously reported the preparation of a DDS based in zeolite $\mathrm{Y} 50$ with an anticancer drug and demonstrated its efficacy against 51 colorectal carcinoma (CRC) cells in vitro. ${ }^{22}$ CRC is the most 52 common type of tumor in Western countries, being men 53 slightly more often affected. ${ }^{23}$ Treatment of CRC includes 54 surgery, radiotherapy, and/or chemotherapy. However, the 55 treatment design depends largely on the cancer stage. Despite 56 the progress made with the introduction of new cytotoxic 57 agents $^{24-28}$ and medical practices, survival rates of patients with 58 CRC changed little over the last 20 years, ${ }^{29}$ justifying the need 59 for more effective therapies and new drugs.

$\alpha$-Cyano-4-hydroxycinnamic acid (CHC) is a compound 61 derived from cinnamic acid and is a competitive inhibitor of 62 monocarboxylate transporter 1 (MCT1), ${ }^{30}$ a protein recently 63 shown to be upregulated in colorectal and other cancers and 64 thus a potential target for cancer therapy. ${ }^{31-33}$ Published data 65 demonstrated the cytotoxic and cytostatic effectiveness of 66 $\mathrm{CHC},{ }^{34,35}$ both in vitro and in vivo. ${ }^{36,37} \mathrm{CHC}$ used here in a 67 model of colon carcinoma was chosen as a guest in two 68 different structures of zeolites for drug delivery. Due to their 69 structural properties, zeolites have attracted much research 70

Received: September 21, 2012

Revised: November 7, 2012 
71 attention for their potential application in the fields of 72 biotechnology, selective adsorption, heterogeneous catalysis, 73 polymer catalytic degradation, and functional materials. ${ }^{4,38-41}$

74 The faujasite framework of zeolite $\mathrm{Y}$ is based on sodalite 75 cages that are joined by oxygen bridges between the hexagonal 76 faces. Eight sodalite cages are linked together, forming a large 77 central cavity or supercage with a diameter of $1.18 \mathrm{~nm}$. The 78 supercages share a 12 -membered ring with an open diameter of $790.74 \mathrm{~nm} .{ }^{42}$ However, zeolite A exhibits LTA (Linde Type A) 80 structure with small pores. The pore diameter is defined by an 81 eight-member oxygen ring with an open diameter of $0.42 \mathrm{~nm}$. 82 This leads into a larger cavity of minimum free diameter 1.14 $83 \mathrm{~nm}$. The cavity is surrounded by eight sodalite cages (truncated 84 octahedra), connected by their square faces in a cubic 85 structure. $^{43-45}$

86 In this study, we present the results obtained with two 87 different synthetic structures of zeolites, faujasite (FAU) and 88 Linde type A (LTA), and their suitability as drug delivery 89 systems (DDS) for the anticancer drug CHC. The zeolites in 90 sodium form $(\mathrm{NaY}$ and $\mathrm{NaA}$ ) were used for encapsulation of $91 \mathrm{CHC}$ as a guest by diffusion in the liquid phase in the void 92 space of the host zeolite porosity. The effect of the CHC 93 concentration in both zeolites was studied. These new DDS 94 were characterized by different methods (FTIR, ${ }^{1} \mathrm{H}$ NMR, ${ }^{13} \mathrm{C}$ 95 and ${ }^{27} \mathrm{Al}$ solid-state MAS NMR, UV-vis, SEM, XRD, and 96 elemental analysis). The effect of the zeolites and CHC@ 97 zeolite DDS was evaluated on HCT-15 human colon carcinoma 98 cell viability.

\section{EXPERIMENTAL SECTION}

100 Preparation and Characterization of DDS. The zeolitic 101 structures are commercially available; FAU zeolite in powder 102 form (CBV100) was obtained from Zeolyst International and 103 Linde type A zeolite from Sigma-Aldrich (European Commis104 sion, Institute for Reference Materials and Measurements, 105 BCR-705). Zeolite $\mathrm{NaA}$ was available in pellet form with clay 106 impurities and was transformed in powder before use. The 107 encapsulation of $\mathrm{CHC}(\alpha$-cyano-4-hydroxycinnamic acid, 108 Sigma-Aldrich) in zeolites was based on a previously established 109 procedure. $^{20}$ Zeolites were dehydrated at $120{ }^{\circ} \mathrm{C}$ overnight, 110 prior to insertion of the drug, to avoid the presence of water 111 inside the pores, which renders the adsorption of the drug 112 molecules more difficult. CHC encapsulation into the zeolites 113 was achieved as follows: $500 \mathrm{mg}$ of each zeolite with different $114 \mathrm{Si} / \mathrm{Al}$ atomic ratios, $\mathrm{NaY}(\mathrm{Si} / \mathrm{Al}$ ratio $=2.83)$ and $\mathrm{NaA}(\mathrm{Si} / \mathrm{Al}$ 115 ratio $=1.24)$ was reacted with a solution of $49.20 \mathrm{mg}$ of $\mathrm{CHC}$ $116(0.26 \mathrm{mmol})$ in acetone $(15 \mathrm{~mL}$, Merck analytical grade), as a 117 solvent. This mixture was carried out by stirring at room 118 temperature for $48 \mathrm{~h}$. During this time, the original white color 119 of zeolites changed to the characteristic color of the $\mathrm{CHC}$, 120 yellow, indicating that the drug species were effectively 121 incorporated inside the host. This finding was also confirmed 122 by the disappearance of the yellow color of the starting $\mathrm{CHC}$ 123 solution after $3 \mathrm{~h}$ in contact with the zeolite and the efficiency 124 of the encapsulation was screened by HPLC.

125 The mixture was filtered and the yellow solid was dried in an 126 oven at $60{ }^{\circ} \mathrm{C}$ for $12 \mathrm{~h}$. This temperature is enough to 127 evaporate the acetone solvent. Two other samples with 128 different $\mathrm{CHC}$ concentrations, $98.40 \mathrm{mg}$ of $\mathrm{CHC}(0.52$ $129 \mathrm{mmol})$ and $246.00 \mathrm{mg}$ of CHC $(1.30 \mathrm{mmol})$, were prepared 130 in both zeolites under the same experimental conditions. The 131 obtained DDS were denoted as CHC@zeolite ${ }_{n}$, where $n$ 132 represents the $\mathrm{CHC}$ :zeolite ratio. The drug loading in the zeolites was determined by gravimetric analysis. In this 133 technique, loading was obtained between the difference in 134 weights of the powder starting zeolite and the DDS prepared by 135 using an analytical balance (Precisa 40SM-200A $\pm 0.00001 \mathrm{~g}$ ). 136 In order to evaluate the solvent effect, the zeolites were 137 prepared with $15 \mathrm{~mL}$ of solvent, using the same experimental 138 conditions as the CHC@zeolites samples.

Characterization Methods. ${ }^{13} \mathrm{C}$ cross-polarization/magic 140 angle spinning nuclear magnetic resonance $\left({ }^{13} \mathrm{C} \mathrm{CP} / \mathrm{MAS} 141\right.$ NMR) and MAS ${ }^{27} \mathrm{Al}$ spectra were recorded on a 9.4 $\mathrm{T}$ wide- 142 bore (400 MHz, ${ }^{1} \mathrm{H}$ Larmor frequency) Bruker Avance 143 spectrometer. A $4 \mathrm{~mm}$ double-resonance MAS probe was 144 employed at $100.6\left({ }^{13} \mathrm{C}\right)$ and $104.2 \mathrm{MHz}\left({ }^{27} \mathrm{Al}\right)$ Larmor 145 frequencies. Samples were spun in $\mathrm{ZrO}_{2}$ rotors, using a 146 spinning rate of $14 \mathrm{kHz} .{ }^{13} \mathrm{C} \mathrm{CP} / \mathrm{MAS}$ NMR spectra were 147 recorded with use of a ramp step (varying from $100 \%$ to $50 \%$ in 148 amplitude using 100 points); contact time: $3.0 \mathrm{~ms} ;{ }^{1} \mathrm{H} 90^{\circ}{ }_{149}$ excitation pulse: $2.5 \mu \mathrm{s} ;{ }^{1} \mathrm{H}$ and ${ }^{13} \mathrm{C}$ radio frequency field 150 strengths for $\mathrm{CP}$ were set to 87 and $68 \mathrm{kHz}$, respectively; 151 recycle delay: 5 s. TPPM-15 decoupling was employed during 152 the signal acquisition, using a $4.75 \mu$ s pulse length for the basic 153 TPPM pulse unit along the ${ }^{1} \mathrm{H}$ channel, employing a ${ }^{1} \mathrm{H}$ radio 154 frequency field strength of $100 \mathrm{kHz}$. For the ${ }^{27} \mathrm{Al}$ MAS 155 experiments, a $0.50 \mu \mathrm{s}$ pulse length was applied, equivalent to a 156 flip angle of $10^{\circ} .{ }^{13} \mathrm{C}$ chemical shifts are quoted in parts per 157 million (ppm) from TMS and calibrated with respect to the 158 external reference, glycine (CO, $176.03 \mathrm{ppm})$. All ${ }^{27} \mathrm{Al}$ chemical 159 shifts were referenced with respect to an aqueous solution of 160 $\mathrm{Al}\left(\mathrm{NO}_{3}\right)_{3}$. All samples were kept in a sealed container and 161 exposed to a saturated solution of $\mathrm{K}_{2} \mathrm{SO}_{4}$ (relative humidity of 162 97\%) for two weeks, prior to the acquisition of solid-state NMR 163 data. This experimental protocol was necessary to guarantee the 164 full hydration of the samples and therefore the reproducibility 165 of the results. The quantitative analysis ( $\mathrm{Si}, \mathrm{Al}$, and $\mathrm{Na}$ ) was 166 carried out by Inductively Coupled Plasma Atomic Emission 167 Spectrometry (ICP-AES), using a Philips ICP PU 7000168 spectrometer. Elemental analyses for carbon, nitrogen, and 169 hydrogen were carried out on LECO CHNS-932 equipment. 170 Samples were combusted at $1000{ }^{\circ} \mathrm{C}$ for $3 \mathrm{~min}$ with helium 171 used as the purge gas. ${ }^{1} \mathrm{H}$ NMR spectra were obtained on a 172 Varian Unity Plus spectrometer at an operating frequency of 173 $300 \mathrm{MHz}$, using the solvent peak as internal reference at $25^{\circ} \mathrm{C}, 174$ chemical shifts of protons being given in ppm using $\delta_{\mathrm{H}} \mathrm{Me}_{4} \mathrm{Si}={ }_{175}$ $0 \mathrm{ppm}$ as reference. The electronic UV-visible absorption 176 spectra of drug and residual solutions were collected in the 177 range 600-200 $\mathrm{nm}$ in a Shimadzu UV/2501PC spectropho- 178 tometer, using quartz cells at room temperature. Phase analysis 179 was performed by XRD with a Philips PW1710 diffractometer. 180 Scans were taken at room temperature in a $2 \theta$ range between 181 $5^{\circ}$ and $60^{\circ}$, using $\mathrm{Cu} \mathrm{K \alpha}$ radiation. Scanning electron 182 micrographs (SEM) were collected on a LEICA Cambridge 183 S360 scanning microscope equipped with an EDX system. To 184 avoid surface charging, samples were coated with gold under 185 vacuum prior to analysis, using a Fisons Instruments SC502 186 sputter coater. The analysis was carried out by high 187 performance liquid chromatography (HPLC JASCO 980-PU), 188 using an isocratic pump and a double on line detection 189 including an UV-vis detector and refractometer. Room 190 temperature Fourier transform infrared (FTIR) spectra of the 191 samples in $\mathrm{KBr}$ pellets ( $2 \mathrm{mg}$ of sample was mixed in a mortar 192 with $200 \mathrm{mg}$ of $\mathrm{KBr}$ ) were measured with a Bomem MB104 193 spectrometer in the range $4000-500 \mathrm{~cm}^{-1}$ by averaging 20194 scans at a maximum resolution of $4 \mathrm{~cm}^{-1}$. 
196 Cell Culture Conditions. Human colon carcinoma-derived 197 cell line HCT-15 was kindly provided by Dr. Raquel Seruca, 198 (IPATIMUP, Porto, Portugal). HCT-15 colon carcinoma cells 199 were maintained in RPMI 1640 medium (Gibco), supple200 mented with $10 \%(\mathrm{v} / \mathrm{v})$ fetal bovine serum (FBS) (Gibco, 201 Invitrogen, USA) and $1 \%(\mathrm{v} / \mathrm{v})$ penicillin-streptomycin 202 solution (P/S) (Invitrogen, USA) and incubated at $37{ }^{\circ} \mathrm{C}$ in 203 a $5 \% \quad \mathrm{CO}_{2}$ humidified atmosphere. Cells were subcultured 204 approximately every three days and maintained in a log-phase 205 growth.

206 Cell Viability Assays. Cell viability was assessed using the 207 In Vitro Toxicology Assay Kit, Sulforhodamine B based (Sigma208 Aldrich, St. Louis, MO, USA). HCT-15 cells were seeded in 96209 well plates (5000 cells $/ 100 \mu \mathrm{L} /$ well) and incubated at $37{ }^{\circ} \mathrm{C}$ in 210 a $5 \% \mathrm{CO}_{2}$ humidified atmosphere for $24 \mathrm{~h}$. To assess the effects 211 of the starting zeolites and the CHC@zeolite systems used $212(\mathrm{NaA}$ and $\mathrm{NaY})$, cells were incubated with increasing 213 concentrations of the systems in culture medium. Controls 214 were performed with culture medium alone. After an 215 incubation period of $24 \mathrm{~h}$, the spent media were removed 216 and the plate wells were washed with $1 \times$ Phosphate-buffered 217 solution, $\mathrm{pH} 7.4$ (PBS). After a fixation step with cold $10 \%$ 218 trichloroacetic acid (TCA), cells were stained with $0.4 \%$ 219 Sulforhodamine B and the incorporated dye was solubilized 220 with Sulforhodamine B solubilization solution (10 mM Tris). 221 Absorbance was monitored with a microplate reader at $570 \mathrm{~nm}$ 222 with a background absorbance of $655 \mathrm{~nm}$. Cell viability was 223 determined as percentage of viability: (OD experiment/OD 224 control $) \times 100(\%)$. Results are presented as mean \pm standard 225 deviation (SD) of three independent experiments, each in 226 triplicate. One-way ANOVA, followed by Dunnett post test was 227 used to perform cell viability assay statistical analysis. The 228 previous test and 50\% growth inhibition (IC50) were 229 determined with Graphpad Prism 5 software. Values were 230 considered statistically significant in all experiments when $p<$ 2310.05 .

\section{RESULTS AND DISCUSSION}

233 Preparation and Characterization of DDS. In the 234 present study, the anticancer drug $\mathrm{CHC}$ was chosen to test

\section{Table 1. Loading of $\mathrm{CHC}$ in the DDS}

$\begin{array}{cccc}\text { DDS } & \mathrm{CHC}(\mathrm{mmol})^{a} & \mathrm{CHC}(\mathrm{mmol})^{b} & \text { yield }(\%)^{c} \\ \mathrm{CHC}^{c} \mathrm{~A}_{1: 10} & 0.260 & 0.198 & 76.2 \\ \mathrm{CHC}_{2} @ \mathrm{~A}_{2: 10} & 0.520 & 0.377 & 72.5 \\ \mathrm{CHC}_{5: 10} & 1.300 & 0.876 & 67.4 \\ \mathrm{CHC} @ \mathrm{Y}_{1: 10} & 0.259 & 0.226 & 87.3 \\ \mathrm{CHC} @ \mathrm{Y}_{2: 10} & 0.517 & 0.438 & 84.8 \\ \mathrm{CHC} @ \mathrm{Y}_{5: 10} & 1.310 & 1.081 & 82.5 \\ { }^{a} \text { Initial CHC amount in the solution. }{ }^{b} \mathrm{CHC} \text { loading in zeolite. } \\ { }^{c} \text { Encapsulation efficiency of CHC in zeolites. }\end{array}$

235 the use of zeolite structures as DDSs. The approach for the 236 preparation of DDS was the adsorption of CHC as a guest in 237 liquid phase within the framework of the zeolite as a host. This 238 approach required that the drug diffused inward the space 239 available of the zeolite framework and the starting zeolites were 240 not cytotoxic to the HCT-15 cell line. In this cell line, 241 preliminary studies with $\mathrm{NaY}, \mathrm{NaMOR}, \mathrm{NaA}$, and ZSM5 were 242 also carried out. NaY (Faujasite) and $\mathrm{NaA}$ structures (Linde 243 type A) showed to be nontoxic to the cells.
Both zeolites have different pore diameters, large pores for 244 $\mathrm{NaY}(7.4 \AA)$ and small pores for $\mathrm{NaA}(4.2 \AA)$, which can 245 determine the access of $\mathrm{CHC}$ into the structures. However, for 246 $\mathrm{CHC}$ the length between the $\mathrm{OH}$ group from the aryl ring and 247 the $\mathrm{COOH}$ is approximately $10.6 \AA$ in the planar and linear 248 molecule, and the aryl ring is $5.9 \AA$, suggesting that this drug 249 could have some difficulty in diffusing into the $\mathrm{NaA}$ zeolite 250 structure. The loading of $\mathrm{CHC}$ into the zeolites was determined 251 by gravimetric analysis. Table 1 shows the loading obtained for $252 \mathrm{tl}$ all prepared DDS.

253

The residual drug content in solution after evaporation of the 254 solvent is very low. In the case of $\mathrm{NaY}$ zeolite, around $85 \%$ of 255 the $\mathrm{CHC}$ initially present has been retained inside this zeolite. 256 However, for $\mathrm{NaA}$, only $67-76 \%$ of the $\mathrm{CHC}$ was incorporated 257 into the structure.

To confirm the integrity of the molecular structure of CHC 259 after preparation of DDS, ${ }^{1} \mathrm{H}$ NMR and UV-vis experiments 260 were performed with the residual drug solid obtained after 261 filtration and pure $\mathrm{CHC}$. The ${ }^{1} \mathrm{H}$ NMR spectra of the samples 262 were recorded at $300 \mathrm{MHz}$ in $\mathrm{CDCl}_{3}$. The chemical shifts of 263 protons observed for residual drug are $\delta 13.3(\mathrm{~s}, \mathrm{COOH}), 10.6264$ $(\mathrm{s}, \mathrm{OH}), 8.3(\mathrm{~s}, \mathrm{CH}=)$ ), and 7.8 and 6.7 (2ddd, $4 \mathrm{H}$ from the 265 aryl group). These chemical shifts of protons are in the same 266 position as observed for the CHC pure molecule. ${ }^{46}$ In the UV- 267 vis spectrum, the presence of residual drug was evidenced by 268 the appearance of an intense band $\left(\lambda_{\max }=334 \mathrm{~nm}\right)$ in the same 269 position of $\mathrm{CHC}$ in acetone $\left(\lambda_{\max }=337 \mathrm{~nm}\right){ }^{46}$ These results 270 show that the encapsulation process preserved the integrity of 271 CHC.

Preservation of the zeolite structures of the DDS was 273 monitored by powder X-ray diffraction (XRD). The powder 274 XRD diffraction patterns of the zeolites and encapsulated CHC 275 were recorded at $2 \theta$ values between $5^{\circ}$ and $60^{\circ}$. The parent 276 zeolite Y sample is pure, while LTA is contaminated with a 277 small amount of an unidentified phase displaying a main 278 resonance at $26.6^{\circ} 2 \theta$ probably due to the presence of clay in 279 the pellet form. All samples exhibited XRD patterns similar to 280 the patterns of the parent zeolites. No variation was observed in 281 the characteristic peaks of zeolites after encapsulation of $\mathrm{CHC}, 282$ indicating that the frameworks did not undergo any significant 283 structural change during the CHC encapsulation process. The 284 XRD pattern of DDS prepared with NaY presented over $85 \% 285$ of crystallinity, while for $\mathrm{NaA}$ the crystallinity was ca. $75 \% . \quad 286$

The morphology of the DDS obtained after the encapsula- 287 tion was observed by SEM analysis. Figure 1 shows the parent $288 \mathrm{fl}$ zeolites and the DDS with lower concentration of CHC. 289

The SEM micrographs of parent zeolites and the DDS 290 indicate that no changes occur in the morphology and structure 291 upon encapsulation of the drug. In panels a and c of Figure 1, it 292 is clear from the micrographs of NaY and CHC@Y $1: 10$ that the 293 morphology of the zeolite does not change after encapsulation 294 of the CHC. The SEM microphotographs of the parent NaY 295 and the DDS are typical of a microporous crystalline 296 aluminosilicate structure with regular small particles. ${ }^{47,48}$ The 297 average of the particle diameter of the starting $\mathrm{NaY}$ was about 298 0.4-1.0 $\mu \mathrm{m}$ and the DDS preserved the same diameter. The 299 starting NaA (Figure 1b) and its DDS (Figure 1d), two types of 300 particles with different dimensions, can be observed: (i) 301 aggregates of particles with a diameter of $\sim 2.6-5.0 \mu \mathrm{m}$ and 302 (ii) particles with a diameter of $\sim 0.3-1.0 \mu \mathrm{m}$. However, for 303 both DDS, the energy-dispersive X-ray analysis plots detected 304 the presence of nitrogen from the $\mathrm{CHC}$ molecule on the 305 spotted surface. 

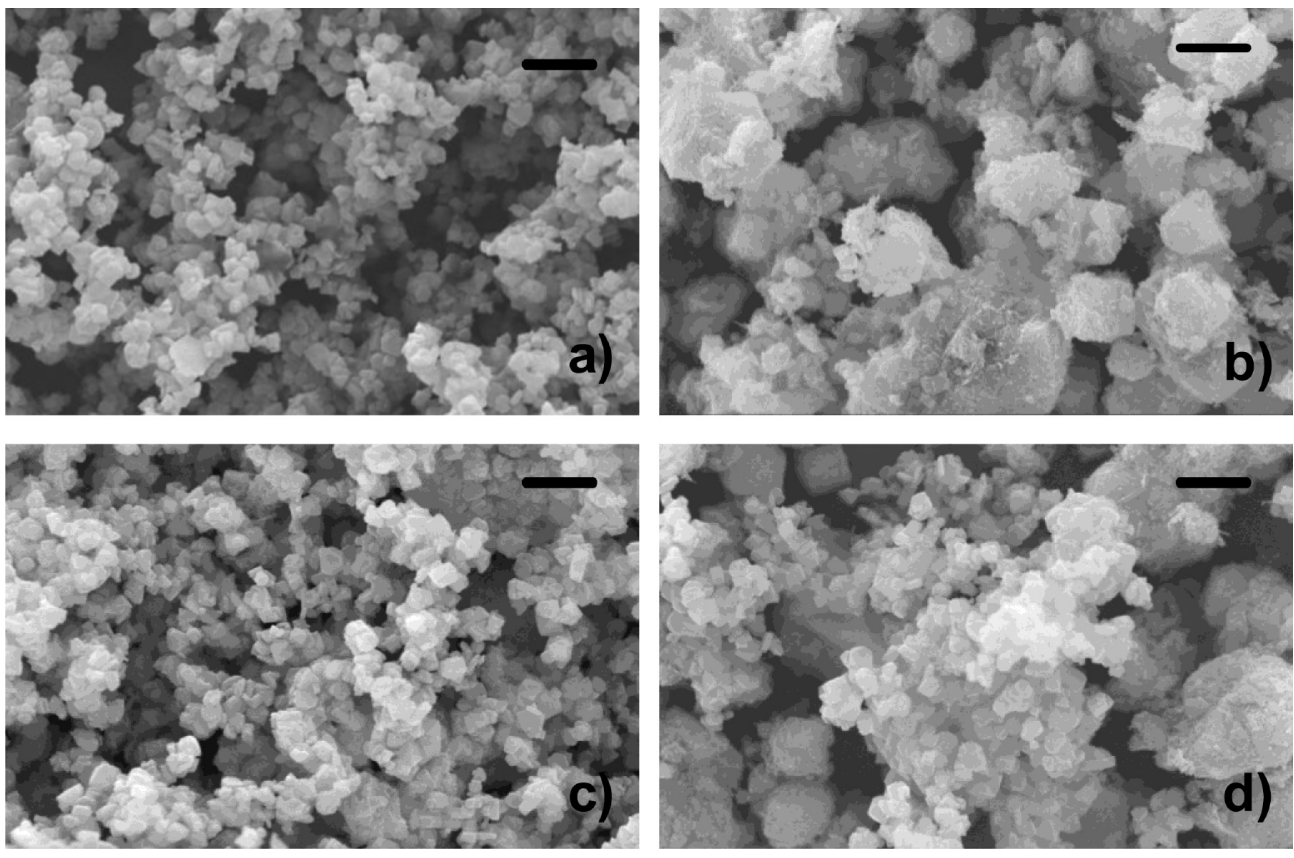

Figure 1. Scanning electron microscopy (SEM) images of zeolites and DDS herein studied. Scale bars represent $5 \mu \mathrm{m}: \mathrm{NaY}$ (a), NaA (b), CHC@ $\mathrm{Y}_{1: 10}(\mathrm{c})$, and CHC@A $\mathrm{A}_{1: 10}(\mathrm{~d})$ with the same resolution $(\times 5000)$.

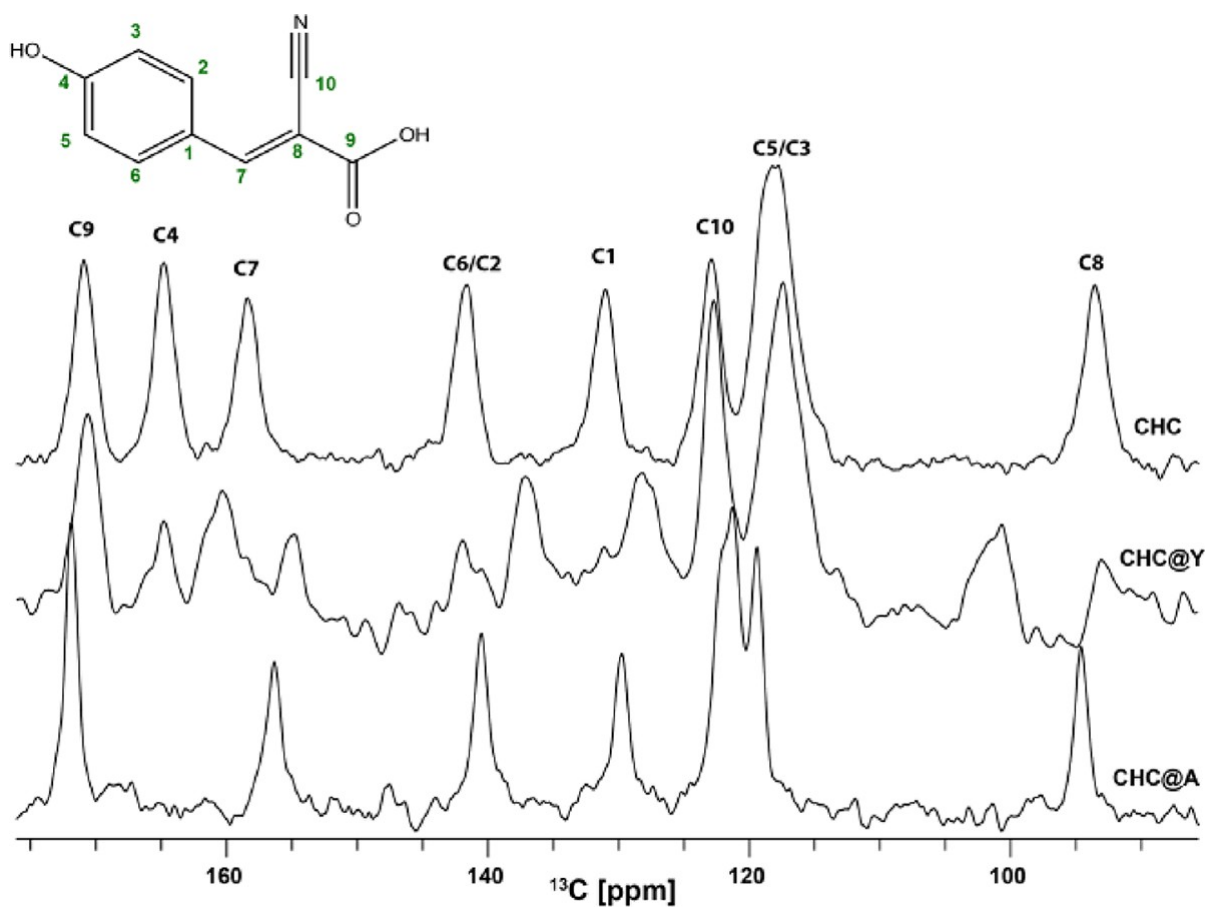

Figure 2. ${ }^{13} \mathrm{C} \mathrm{CP} / \mathrm{MAS}$ NMR spectra of $\mathrm{CHC}, \mathrm{CHC}_{1: 10}$, and $\mathrm{CHC}_{1: 10}$.

307 The integrity of the $\mathrm{CHC}$ in zeolites was confirmed by the 308 analytical data of carbon and nitrogen content obtained by 309 elemental analysis. The theoretical $\mathrm{C} / \mathrm{N}$ ratio for $\mathrm{CHC}$ is 8.6 310 (63.49\% to $\mathrm{C}$ and $7.40 \%$ to $\mathrm{N}$ ). All samples based in different 311 zeolites present a similar $\mathrm{C} / \mathrm{N}$ ratio. For example, the guest $\mathrm{C} /$ $312 \mathrm{~N}$ ratio obtained for $\mathrm{CHC}_{1: 10}$ is 8.7 (1.66\% to $\mathrm{C}$ and $0.19 \%$ 313 to $\mathrm{N})$ and for $\mathrm{CHC}_{1: 10}$ it is $8.3(1.49 \%$ to $\mathrm{C}$ and $0.18 \%$ to $314 \mathrm{~N}$ ), indicating the presence of the molecular drug structure in 315 the zeolite.

316 Evidence for the interaction between $\mathrm{CHC}$ and the zeolites is 317 forthcoming from spectroscopic data. The ${ }^{13} \mathrm{C} C P / M A S ~ N M R$ spectra of CHC, CHC@Y $\mathrm{Y}_{1: 10}$, and CHC@A $\mathrm{A}_{1: 10}$ are shown in 318 Figure 2 .

The spectrum of CHC shows the characteristic peaks of the 320 drug molecule, consistent with the assignment previously 321 reported for similar compounds. ${ }^{49}$ Peaks in the same spectral 322 regions appear in both encapsulated zeolites, indicating the 323 presence of $\mathrm{CHC}$ in the pores of the materials. The differences 324 between the spectra of the pure and the zeolite-encapsulated 325 samples are attributed to drug interactions with and/or 326 conformational changes induced by the presence of $\mathrm{Na}^{+}$ions, 327 

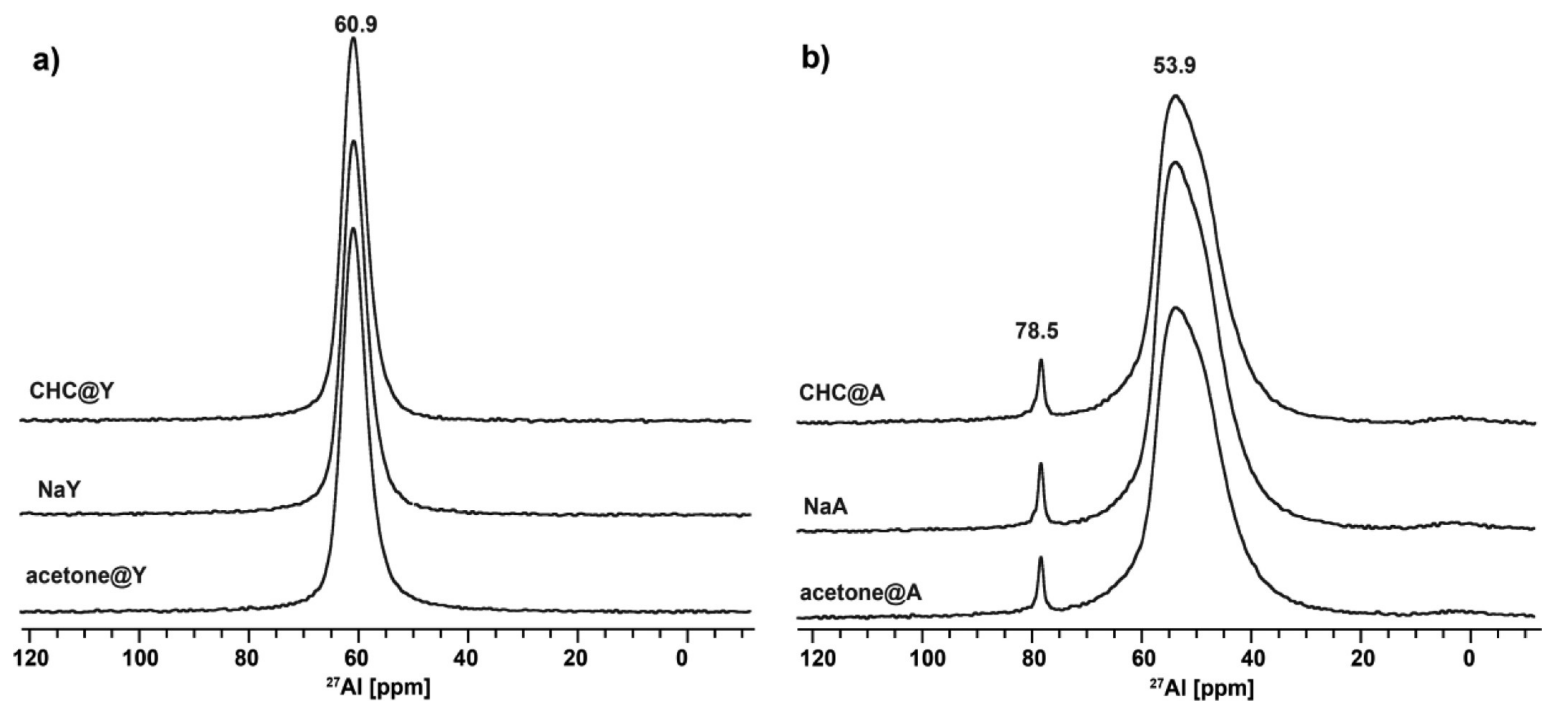

Figure 3. ${ }^{27} \mathrm{Al}$ MAS NMR spectra of parent Y (a) and LTA (b) zeolites and in the presence of solvents: acetone@zeolite and CHC@zeolite $1: 10$.
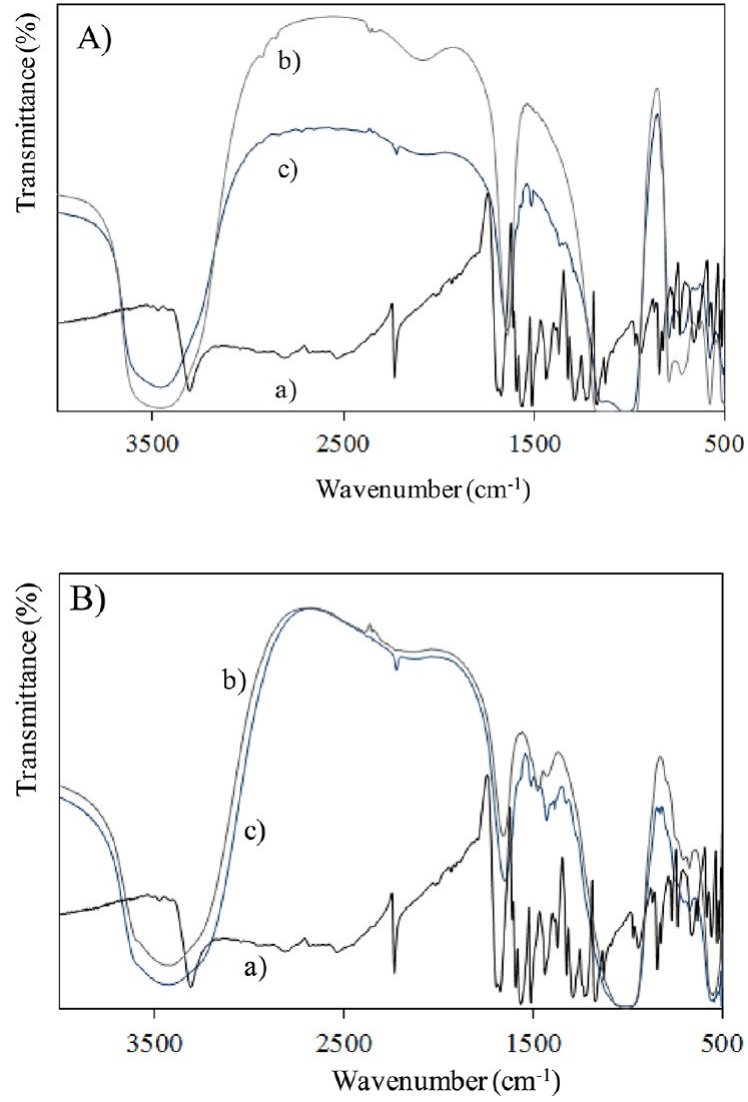

Figure 4. FTIR spectra of $\mathrm{NaY}(\mathrm{A})$ and $\mathrm{NaA}$ (B) for $\mathrm{CHC}(\mathrm{a})$, zeolites (b), and CHC@zeolite $1: 10$ (c).

328 water molecules, and/or the zeolite framework. These 329 observations are consistent with the FTIR results (see below). 330 The effect of the solvent on the preparation of the samples 331 was also studied by ${ }^{27} \mathrm{Al}$ MAS NMR. The ${ }^{27} \mathrm{Al}$ MAS NMR 332 spectra of the parent zeolites, CHC@zeolites ${ }_{1: 10}$ and acetone@ 333 zeolites, are shown in Figure 3.

334 All samples contain four-coordinated aluminum framework 335 species $\left[\mathrm{Al}(\mathrm{OSi})_{4}\right]$, as revealed by the peaks at $60.9 \mathrm{ppm}$ for $\mathrm{Y}$ 336 and $53.9 \mathrm{ppm}$ for LTA samples. No shift or broadening of the $337{ }^{27} \mathrm{Al}$ peaks were observed upon introduction of the solvent or
Table 2. Final Assay Concentrations of CHC in the Different DDS

\begin{tabular}{ccccc} 
& $\begin{array}{c}\mathrm{DDS} 1.00 \\
\mathrm{mg} / \mathrm{mL} \\
(\mathrm{mM})\end{array}$ & $\begin{array}{c}\mathrm{DDS} 0.25 \\
\mathrm{mg} / \mathrm{mL} \\
(\mathrm{mM})\end{array}$ & $\begin{array}{c}\mathrm{DDS} 0.10 \\
\mathrm{mg} / \mathrm{mL} \\
(\mathrm{mM})\end{array}$ & $\begin{array}{c}\mathrm{DDS} 0.05 \\
\mathrm{mg} / \mathrm{mL} \\
(\mathrm{mM})\end{array}$ \\
$\begin{array}{c}\mathrm{CHC} @ \mathrm{~A} \\
\text { 1:10 }\end{array}$ & 0.198 & 0.050 & 0.020 & 0.010 \\
$\begin{array}{c}\text { CHC@A } \\
\text { 2:10 }\end{array}$ & 0.377 & 0.094 & 0.038 & 0.019 \\
$\begin{array}{c}\text { CHC@A } \\
\text { 5:10 }\end{array}$ & 0.876 & 0.219 & 0.088 & 0.044 \\
$\begin{array}{c}\text { CHC@Y } \\
\text { 1:10 }\end{array}$ & 0.226 & 0.057 & 0.023 & 0.011 \\
$\begin{array}{c}\text { CHC@Y } \\
\text { 2:10 }\end{array}$ & 0.435 & 0.109 & 0.044 & 0.022 \\
$\mathrm{CHC} @ \mathrm{Y}$ & 1.081 & 0.270 & 0.108 & 0.054 \\
$5: 10$ & & & & \\
\hline
\end{tabular}

upon drug-molecule encapsulation, including no changes in the 338 octahedral-coordinated region (even if a faint broad peak at ca. 339 5 ppm, presumably from the impurity, is observed for all LTA 340 samples), indicating that the experimental procedures do not 341 provoke damages in the structure in agreement with XRD and 342 SEM analyses. The same behavior was observed in the ${ }^{23} \mathrm{Na} 343$ solid-state MAS NMR spectra. The faint and sharp ${ }^{27} \mathrm{Al} 344$ resonance at 78.5 observed in the spectra of the LTA samples 345 (Figure $3 \mathrm{~b}$ ) is assigned to the unknown impurity contaminating 346 the parent sample and also revealed by XRD.

The presence of the drug and its interactions in both zeolites 348 are also screened by Fourier transformed infrared spectroscopy 349 (FTIR). Figure 4 shows the infrared spectra of $\mathrm{NaY}(\mathrm{A})$ and $350 \mathrm{f} 4$ $\mathrm{NaA}$ (B) for CHC (a), zeolites (b), and CHC@zeolite 1:10 $_{\text {(c).351 }}$

The FTIR spectrum of $\mathrm{CHC}$ (Figure $4 \mathrm{a}$ ) shows the presence 352 of $\nu(\mathrm{C} \equiv \mathrm{N})$ at $2230 \mathrm{~cm}^{-1}, \nu(\mathrm{C}=\mathrm{O})$ at $1678 \mathrm{~cm}^{-1}$, and the 353 vibrational bands characteristic of the $\mathrm{C}-\mathrm{C}$ and $\mathrm{C}-\mathrm{H}$ groups 354 around 1550 and $1150 \mathrm{~cm}^{-1}$. For the prepared DDS, the FTIR 355 spectra of zeolites and the samples are dominated by the strong 356 bands assigned to the vibration of the zeolite structure. The 357 presence of physisorbed water is detected by the $\nu(\mathrm{O}-\mathrm{H}) 358$ stretching vibration at $3410 \mathrm{~cm}^{-1}$ and the $\nu(\mathrm{O}-\mathrm{H}) 359$ deformation band at $1635 \mathrm{~cm}^{-1}$. The bands corresponding to 360 the lattice vibrations are observed in the spectral region 361 between 1300 and $450 \mathrm{~cm}^{-1}$. 77,48 

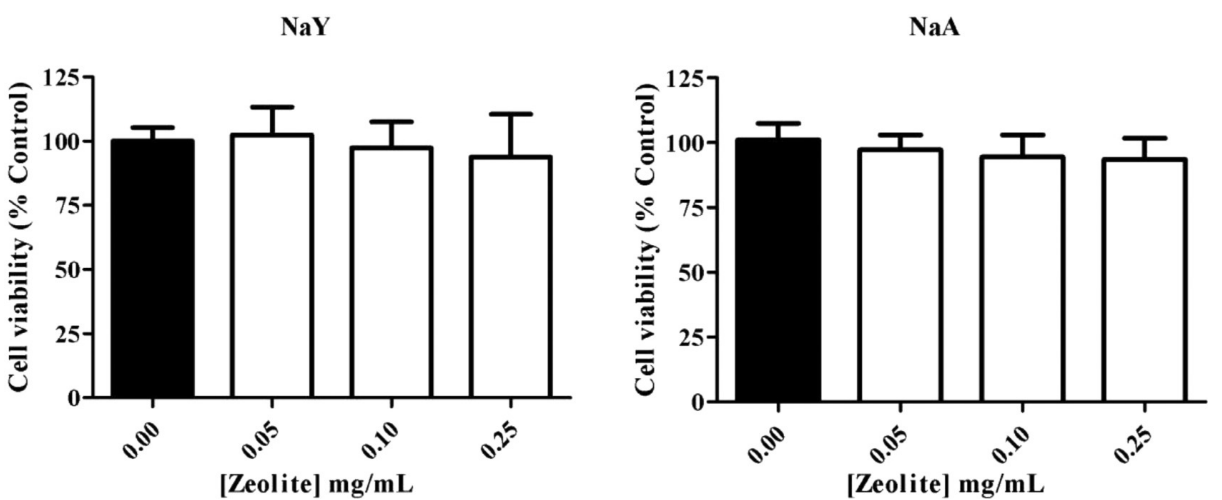

Figure 5. Effect of $\mathrm{NaY}$ and $\mathrm{NaA}$ zeolites on HCT-15 colon carcinoma cell viability. The HCT-15 cell line was incubated with the different zeolite concentrations for $24 \mathrm{~h}$. Cell viability was measured by SRB assay. Values are means \pm SD of three independent experiments, each performed in triplicate. $p<0.05$, compared to the control bar (cells without zeolite).

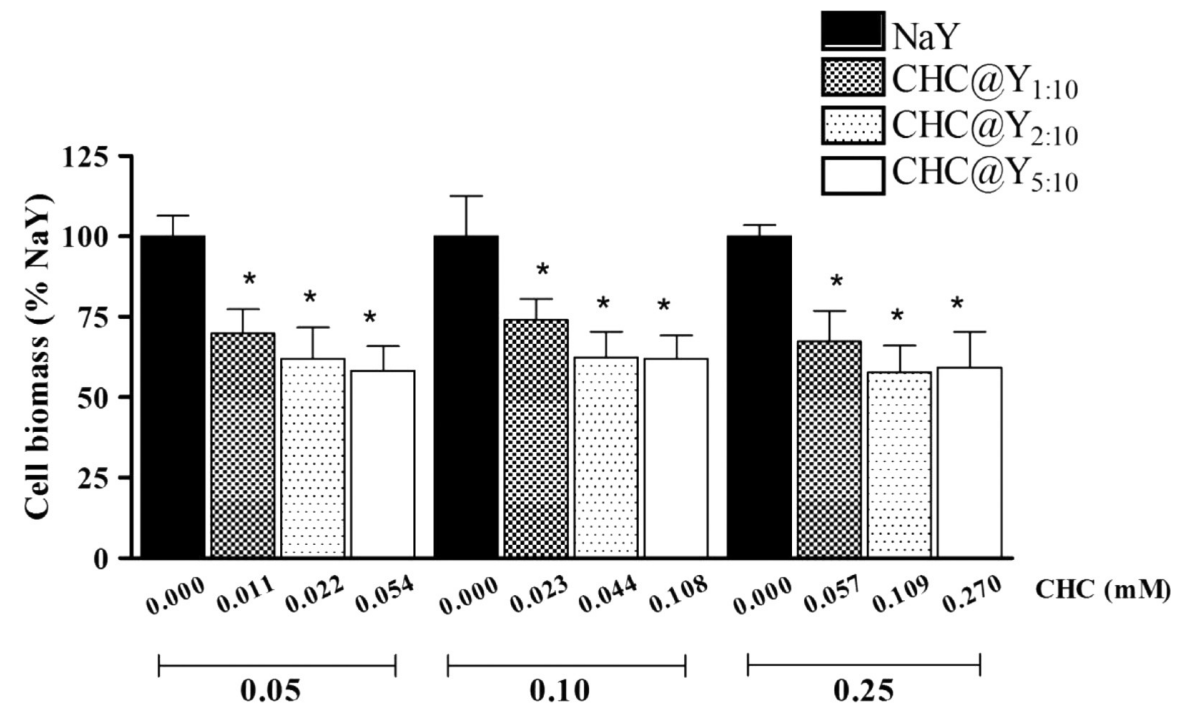

[System] mg/mL

Figure 6. Effect of NaY zeolite and CHC@NaY systems on HCT-15 colon carcinoma cell viability. The HCT-15 cell line was incubated with NaY and different DDS concentrations for $24 \mathrm{~h}$. Cell viability was measured by SRB assay. Values are means \pm SD of three independent experiments, each performed in triplicate. The asterisk indicates $p<0.05$, compared to the control bar $(\mathrm{NaY})$.

363 In addition to these strong bands caused by the host zeolite, 364 the FTIR spectra for CHC@zeolite $1: 10$ (Figure 4c) exhibits 365 bands in the regions $2500-2000 \mathrm{~cm}^{-1}$ and $1600-1200 \mathrm{~cm}^{-1}$ 366 where the zeolites do not absorb and they are attributed to the 367 presence of the encapsulated drug. The spectra of the 368 encapsulated as well as pure $\mathrm{CHC}$ showed similar bands. For 369 example, the spectrum of $\mathrm{CHC} @ \mathrm{~A}_{1: 10}$ shows bands from $\mathrm{CHC}$ 370 at $2216,1506,1419$, and $1311 \mathrm{~cm}^{-1}$. No shift or broadening in 371 the principal zeolite vibrational bands occur upon inclusion of 372 the drug, further substantiating that the zeolite framework 373 remains unchanged. Although the characteristic CHC FTIR 374 vibrational bands in the CHC@zeolite spectra are weak, they 375 provide evidence for the presence of drug in the zeolite. Due to 376 overlap with the strong bands arising from the zeolite 377 framework, it is not possible to draw any further conclusions 378 from these data. NMR spectroscopy is, thus, much more 379 sensitive to molecule structural changes than is FTIR.

380 Drug Bioactivity Studies. Working DDS concentrations $381(0.05,0.10$, and $0.25 \mathrm{mg} / \mathrm{mL})$ were obtained by diluting a stock 382 suspension $(1.00 \mathrm{mg} / \mathrm{mL})$ in culture medium (RPMI1640). 383 For better homogenization, all suspensions were submitted to ultrasonic dispersion for $2 \mathrm{~min}$ prior to use. The concentrations 384 of zeolite suspensions used in this work and the corresponding 385 $\mathrm{CHC}$ final assay concentrations are presented in Table $2 . \quad 386$ t2

To be considered as suitable DDS, zeolites themselves 387 should present small or no effect on cell viability. The 388 cytotoxicity of the starting zeolites was investigated in the 389 HCT-15 cell line. Figure 5 shows the effect of increasing $390 \mathrm{f5}$ amounts of both zeolites $\mathrm{NaY}$ and $\mathrm{NaA}$ on the viability of 391 HCT-15 cells, determined by the SRB assay.

The two zeolites used gave similar results. The differences 393 between controls (without zeolite) and the range of zeolite 394 concentrations are insignificant, showing in this way that both 395 zeolites are nontoxic to the cells for the selected period of 396 incubation. To verify whether the encapsulation of $\mathrm{CHC}$ into 397 zeolites potentiates the effect of this monocarboxylate trans- 398 porter (MCT) inhibitor, the effect of zeolite $\mathrm{NaA}$ and $\mathrm{NaY} 399$ loaded with different amounts of CHC was tested in HCT-15 400 cell viability with increasing concentrations of the CHC@401 zeolite systems $(0.05-0.25 \mathrm{mg} / \mathrm{mL})$. Compared to $\mathrm{NaY}$ alone 402 (control), there is an evident reduction in cell viability, from 403 


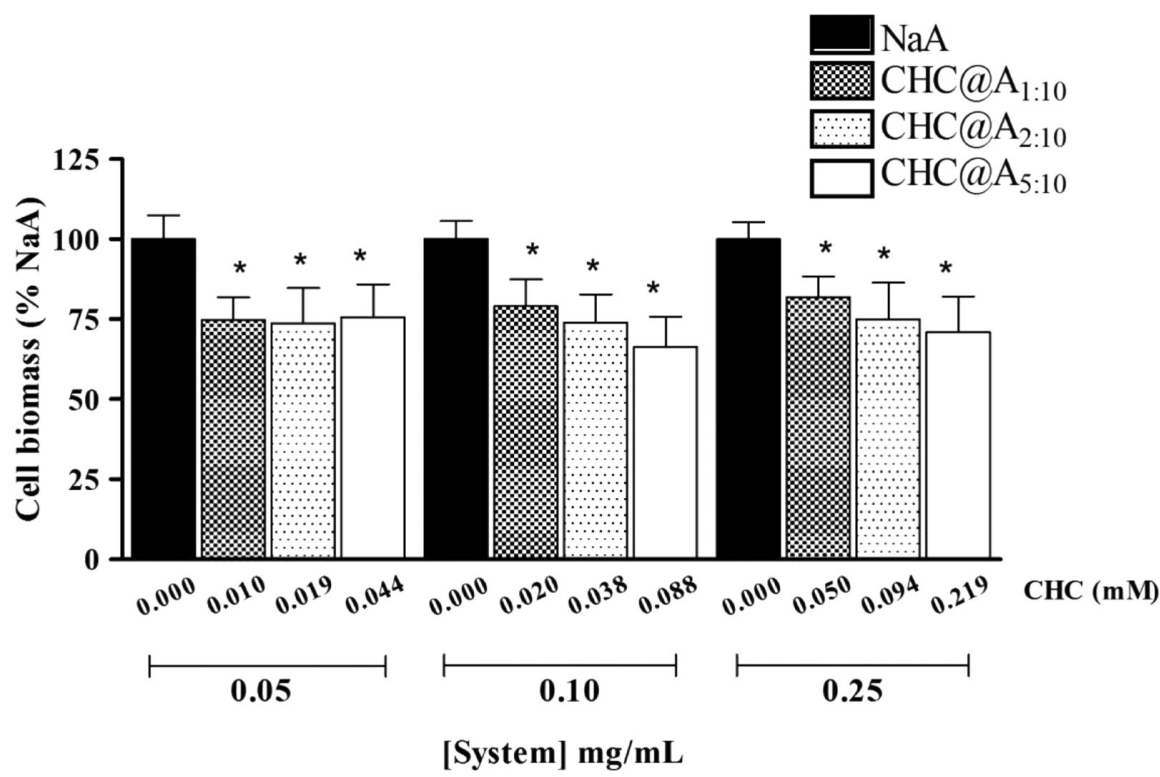

Figure 7. Effect of NaA zeolite and CHC@NaA systems on HCT-15 colon carcinoma cell viability. The HCT-15 cell line was incubated with NaA and different DDS concentrations for $24 \mathrm{~h}$. Cell viability was measured by SRB assay. Values are means \pm SD of three independent experiments, each performed in triplicate. Teh asterisk indicates $p<0.05$, compared to the control bar $(\mathrm{NaA})$.

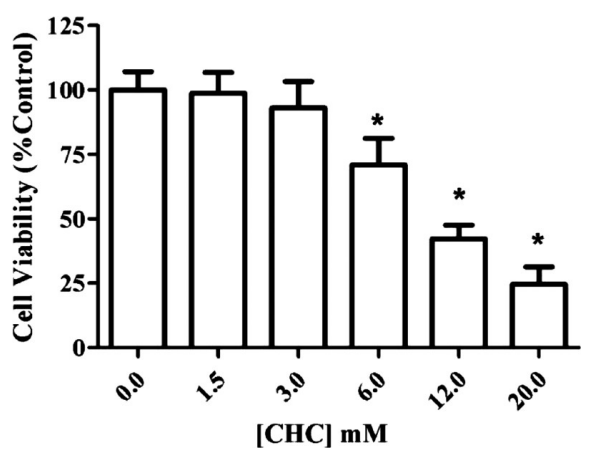

Figure 8. Effect of $\mathrm{CHC}$ on HCT-15 colon carcinoma cell viability. The HCT-15 cell line was incubated with increasing concentrations of $\mathrm{CHC}$ for $24 \mathrm{~h}$. Cell viability was measured by SRB assay. Values are means $\pm \mathrm{SD}$ of three independent experiments, each performed in triplicate. The asterisk indicates $p<0.05$, compared to the control bar (vehicle, no $\mathrm{CHC}$ ).
$40474 \%$ to $58 \%$, with increasing concentrations of $\mathrm{CHC}$ in the 405 zeolite system (Figure 6).

406 The cytotoxic effect of DDS with $\mathrm{NaY}$ was more pronounced 407 for higher concentrations of $\mathrm{CHC}$; however, the effect appears 408 not to be directly proportional to the concentrations of the 409 zeolite suspensions. For CHC@NaA, the cytotoxicity was not 410 as high as for $\mathrm{NaY}$ zeolite, a reduction of cell viability from $82 \%$ 411 to $66 \%$ was obtained when comparing with cells treated with 412 the starting zeolite (Figure 7).

413 Figure 8 shows the effects on cell viability obtained when 414 treating HCT-15 cells with the nonencapsulated CHC. 415 Working concentrations (1.5, 3.0, 6.0, 12.0, and $20.0 \mathrm{mM}$ ) 416 were obtained by diluting the stock solution $(2.9 \mathrm{M})$ in culture 417 medium (RPMI 1640). It is possible to observe a dose418 dependent decrease in cell viability, being the $\mathrm{IC}_{30}$ and $\mathrm{IC}_{50}$ 419 values of $6.43 \mathrm{mM}$ and $10.26 \mathrm{mM}$, respectively.

420 By comparing the results obtained when treating the HCT42115 cells with the nonencapsulated $\mathrm{CHC}$ with the ones of 422 encapsulated $\mathrm{CHC}$, there is an obvious potentiation of the 423 effect of the drug. A $6.43 \mathrm{mM}$ concentration of the nonencapsulated drug is necessary for a $30 \%$ of inhibition of 424 cell viability $\left(\mathrm{IC}_{30}\right)$ (Figure 8 ). In contrast, with the 425 encapsulated drug, for the same magnitude of inhibition and 426 for the $0.05 \mathrm{mg} / \mathrm{mL}$ of concentration zeolite suspension of the 427 different system of CHC@Y, there is an increase in efficiency of 428 the drug between 119- and 585-fold, corresponding to $\mathrm{CHC}_{429}$ assay concentrations of 0.054 and $0.011 \mathrm{mM}$, respectively 430 (Table 2).

The studies for CHC@A showed a lower effect on in-cell 432 viability when compared with $\mathrm{NaY}$. For $30 \%$ inhibition of cell 433 viability, using $0.05 \mathrm{mg} / \mathrm{mL}$ of concentration zeolite suspension 434 of the CHC@A system, there is an efficiency of the drug effect 435 between 29- and 146-fold, corresponding to $\mathrm{CHC}$ assay 436 concentrations of 0.220 and $0.044 \mathrm{mM}$, respectively (Table 2). 437

$\mathrm{NaY}$ DDS was more effective than NaA DDS due to the 438 more open structure of the zeolite $\mathrm{Y}$, in which $\mathrm{CHC}$ could 439 freely diffuse to the outside of the structure toward the cells. 440 However, for higher concentrations of the system or parent 441 zeolite (above $0.25 \mathrm{mg} / \mathrm{mL}$ ), the cell viability begins to be 442 affected, likely due to the compromise of cell-nutrient exchange 443 with the culture media.

444

By encapsulating $\mathrm{CHC}$ into zeolites, we increased signifi- 445 cantly the efficiency of this drug, which could be related to 446 CHC solubility. Since it is a hydrophobic molecule, it is difficult 447 to obtain a homogeneous solution with $\mathrm{CHC}$. Thus, we believe 448 that similarly to other systems, ${ }^{50-53}$ the zeolite DDSs allow the 449 slow release of $\mathrm{CHC}$, increasing the bioavailability of the drug, 450 and thus explaining this increase in potency. Another 451 hypothesis, which would explain the high increase in potency, 452 could be the promotion of CHC entry into the cell. It is 453 described that $\mathrm{CHC}$ could inhibit the entry of pyruvate into the 454 mitochondria, compromising the normal respiration of cells, ${ }^{54} 455$ at much lower concentrations. Thus, this high potency could be 456 the combined result of both the increase in CHC bioavailability ${ }_{457}$ and the promotion of $\mathrm{CHC}$ entry into the cell by the DDS. 458 


\section{$459 \square$ CONCLUSIONS}

460 The studies on the zeolites discussed here demonstrate that 461 these structures can be used effectively for sustained release 462 applications. Two different structures of zeolites, faujasite 463 (FAU) and Linde type A (LTA), were prepared and 464 characterized to assess their ability to encapsulate and release 465 the experimental anticancer drug $\mathrm{CHC}$. The effect of the 466 zeolites and CHC@zeolite DDS on the HCT-15 human colon 467 carcinoma cell line viability was evaluated. Both zeolites alone 468 revealed no toxicity to HCT-15 cancer cells. Importantly, 469 CHC@zeolite led to an inhibition of cell viability up to 585470 fold when compared to the nonencapsulated drug. These 471 results indicate the potential of the zeolites for drug loading and 472 delivery to cancer cells.

\section{$473 \square$ AUTHOR INFORMATION}

\section{Corresponding Author}

475 *E-mail: fbaltazar@ecsaude.uminho.pt (F.B.) and ineves@ 476 quimica.uminho.pt (I.C.N.).

477 Notes

478 The authors declare no competing financial interest.

\section{ACKNOWLEDGMENTS}

480 The authors are thankful to Dr. A. S. Azevedo for collecting the 481 powder diffraction data. O.M. and R.A. are recipients of 482 fellowships (SFRH/BD/36463/2007, SFRH/BI/51118/2010) 483 from Fundação para a Ciência e a Tecnologia (FCT, Portugal). 484 This work was supported by the FCT projects refs PEst-C/ 485 QUI/UI0686/2011, PEst-C/CTM/LA0011/2011, and PTDC/ 486 SAU-FCF/104347/2008, under the scope of "Programa 487 Operacional Temático Factores de Competitividade" (COM488 PETE) of "Quadro Comunitário de Apoio III" and cofinanced 489 by Fundo Comunitário Europeu FEDER, and the Centre of 490 Chemistry and Life and Health Sciences Research Institute 491 (University of Minho, Portugal).

\section{$492 \square$ REFERENCES}

493 (1) Moyano, D. F.; Rotello, V. M. Langmuir 2011, 27, 10376-10385. 494 (2) Danilczuk, M.; Dugopolska, K.; Ruman, T.; Pogocki, D. Mini-Rev. 495 Med. Chem. 2008, 8, 1407-1417.

496 (3) Fatouros, D. G.; Douroumis, D.; Nikolakis, V.; Ntais, S.; 497 Moschovi, A. M.; Trivedi, V.; Khima, B.; Roldo, M.; Nazar, H.; Cox, P. 498 A. J. Mater. Chem. 2011, 21, 7789-7794.

499 (4) Corma, A.; Garcia, H. Eur. J. Inorg. Chem. 2004, 6, 1143-1164. 500 (5) Zhang, Y. H.; Yu, X. J.; Wang, X. Y.; Shan, W.; Yang, P. Y.; Tang, 501 Y. Chem. Commun. 2004, 2882-2883.

502 (6) Corma, A.; Fornes, V.; Rey, F. Adv. Mater. 2002, 14, 71-74.

503 (7) Platas-Iglesias, C.; Van der Elst, L.; Zhou, W. Z.; Muller, R. N.; 504 Geraldes, C. F. G. C.; Maschmeyer, T.; Peters, J. A. Chem.-Eur. J. 505 2002, 8, 5121-5131.

506 (8) Norek, M.; Neves, I. C.; Peters, J. A. Inorg. Chem. 2007, 46, 507 6190-6196.

508 (9) Tsotsalas, M. M.; Kopka, K.; Luppi, G.; Wagner, S.; Law, M. P.; 509 Schafers, M.; De Cola, L. ACS Nano 2010, 4, 342-348.

510 (10) Ndiege, N.; Raidoo, R.; Schultz, M. K.; Larsen, S. Langmuir 511 2011, 27, 2904-2909.

512 (11) Galownia, J.; Martin, J.; Davis, M. E. Microporous Mesoporous 513 Mater. 2006, 92, 61-63.

514 (12) Zhang, H.; Kim, Y.; Dutta, P. K. Microporous Mesoporous Mater. 515 2006, 88, 312-318.

516 (13) Arruebo, M.; Fernandez-Pacheco, R.; Irusta, S.; Arbiol, J.; Ibarra, 517 M. R.; Santamaria, J. Nanotechnology 2006, 17, 4057-4064.

518 (14) Braschi, I.; Gatti, G.; Paul, G.; Gessa, C. E.; Cossi, M.; Marchese, 519 L. Langmuir 2010, 26, 9524-9532.
(15) Braschi, I.; Blasioli, S.; Gigli, L.; Gessa, C. E.; Alberti, A.; 520 Martucci, A. J. Hazard. Mater. 2010, 178, 218-225. 521

(16) Martucci, A.; Pasti, L.; Marchetti, N.; Cavazzini, A.; Dondi, F.; 522 Alberti, A. Microporous Mesoporous Mater. 2012, 148, 174-183. 523

(17) Zarkovic, N.; Zarkovic, K.; Kralj, M.; Borovic, S.; Sabolovic, S.; 524 Blazi, M. P.; Cipak, A.; Pavelic, K. Anticancer Res. 2003, 23, 1589- 525 1595. 526

(18) Dyer, A.; Morgan, S.; Wells, P.; Williams, C. J. Helminthol. 2000, 527 74, 137-141.

(19) Farias, T.; Ruiz-Salvador, A. R.; Rivera, A. Microporous 529 Mesoporous Mater. 2003, 61, 117-125.

(20) Rimoli, M. G.; Rabaioli, M. R.; Melisi, D.; Cucio, A.; Mondello, 531 S.; Mirabelli, R.; Sbignete, E. J. Biomed. Mater. Res., Part A 2008, 87A, 532 $156-164$.

(21) Ceyhan, T.; Tatlier, M.; Akcakaya, H. J. Mater. Sci. Mater. Med. 534 2007, 18, 1557-1562.

(22) Vilaca, N.; Amorim, R.; Martinho, O.; Reis, R. M.; Baltazar, F.; 536 Fonseca, A. F.; Neves, I. C. J. Mater. Sci. 2011, 46, 7511-7516. 537

(23) Jemal, A.; Siegel, R.; Ward, E.; Hao, Y.; Xu, J.; Murray, T.; Thun, 538 M. J. Ca-Cancer J. Clin. 2008, 58, 71-96.

(24) Heidelberger, C.; Chaudhuri, N. K.; Danneberg, P.; Mooren, D.; 540 Griesbach, L.; Duschinsky, R.; Schnitzer, R. J.; Pleven, E.; Scheiner, J. 541 Nature 1957, 179, 663-666.

(25) Ciardiello, F.; Tortor, G. Eur. J. Cancer 2003, 39, 1348-1354. 543

(26) Kabbinavar, F.; Schulz, J.; McCleod, M.; Pattel, T.; Hamm, J.; 544 Hecht, J. R.; Mass, R.; Perrou, B.; Nelson, B.; Novotny, W. F. J. Clin. 545 Oncol. 2005, 23, 3697-3705.

(27) Giantonio, B. J. Nat. Rev. Clin. Oncol. 2009, 6, 311-312.

(28) Odom, D.; Barber, B.; Bennett, L.; Peeters, M.; Zhao, Z. Y.; 548 Kaye, J.; Wolf, M.; Wiezorek, J. Int. J. Colorectal Dis. 2011, 26 (2), 549 $173-181$.

(29) Ozols, R. F.; Herbst, R. S.; Colson, Y. L.; Gralow, J.; Bonner, J.; 551 Curran, W. J.; Eisenberg, B. L.; Ganz, P. A.; Kramer, B. S.; Kris, M. G.; 552 et al. J. Clin. Oncol. 2007, 25, 146-162. 553

(30) Halestrap, A. P.; Meredith, D. Eur. J. Physiol. 2004, 447, 619- 554 628.

(31) Pinheiro, C.; Longatto-Filho, A.; Scapulatempo, C.; Ferreira, L.; 556 Martins, S.; Pellerin, L.; Rodrigues, M.; Alves, V. A. F.; Schmitt, F.; 557 Baltazar, F. Virchows Archs. 2008, 452, 139-146.

(32) Pinheiro, C.; Longatto-Filho, A.; Pereira, S. M. M.; Etlinger, D.; 559 Moreira, M. A. R.; Jubé, L. F.; Queiroz, G. S.; Schmitt, F.; Baltazar, F. 560 Dis. Markers 2009, 26, 97-103.

(33) Pinheiro, C.; Albergaria, A.; Paredes, J.; Sousa, B.; Dufloth, R.; 562 Vieira, D.; Schmitt, F.; Baltazar, F. Histopathology 2010, 56, 860-867. 563

(34) Wahl, M. L.; Owen, J. A.; Burd, R.; Herlands, R. A.; Nogami, S. 564 S.; Rodeck, U.; Berd, D.; Leeper, D. B.; Owen, C. S. Mol. Cancer Ther. 565 2002, 1, 617-628.

(35) Coss, R. A.; Storck, C. W.; Daskalakis, C.; Berd, D.; Wahl, M. L. 567 Mol. Cancer Ther. 2003, 2, 383-388.

(36) Colen, C. B.; Seraji-Bozorgzad, N.; Marples, B.; Galloway, M. P.; 569 Sloan, A. E.; Mathupala, S. P. Neurosurgery 2006, 59, 1313-1323. 570

(37) Sonveaux, P.; Végran, F.; Schroeder, T.; Wergin, M. C.; Verrax, 571 J.; Rabbani, Z. N.; De Saedeleer, C. J.; Kennedy, K. M.; Diepart, C.; 572 Jordan, B. F.; et al. J. Clin. Invest. 2008, 118, 3930-3942. 573

(38) Silva, B.; Figueiredo, H.; Soares, O. S. G. P.; Pereira, M. F. R.; 574 Figueiredo, J. L.; Lewandowska, A. E.; Banares, M. A.; Neves, I. C.; 575 Tavares, T. Appl. Catal., B 2012, 117, 406-413. 576

(39) Kuzniarska-Biernacka, I.; Biernacki, K.; Magalhães, A. L.; 577 Fonseca, A. M.; Neves, I. C. J. Catal. 2011, 278, 102-110. 578

(40) Parpot, P.; Teixeira, C.; Almeida, A. M.; Ribeiro, C.; Neves, I. 579 C.; Fonseca, A. M. Microporous Mesoporous Mater. 2009, 117, 297- 580 303.

(41) Neves, I. C.; Botelho, G.; Machado, A. V.; Rebelo, P.; Ramôa, S.; 582 Pereira, M. F. R.; Ramanathan, A.; Pescarmona, P. Polym. Degrad. Stab. 583 2007, 92, 1513-1519.

(42) Van Santen, R. A.; Kramer, G. J. Chem. Rev. 1995, 95, 637-660. 585

(43) Database of Zeolite Structures from the International Zeolite 586 Association (IZA-SC): www.iza-structure.org/databases/. 
588 (44) Baerlocher, Ch.; McCusker, L. B.; Olson, D. H. Atlas of zeolite 589 framework types; 6th revised ed.; Elsevier: Amsterdam, The Nether590 lands, 2007.

591 (45) Subhash, B. Zeolite Catalysis: Principles and Applications; CRC 592 Press, Inc.: Boca Raton, FL, 1990.

593 (46) Tarzi, O. I.; Nonami, H.; Erra-Balsells, R. J. Mass Spectrom. 594 2009, 44, 260-277.

595 (47) Neves, I. C.; Cunha, C.; Pereira, M. R.; Pereira, M. F. R.; 596 Fonseca, A. M. J. Phys. Chem. C 2010, 114 (24), 10719.

597 (48) Tanaka, K.; Choo, C.-K.; Komatsu, Y.; Hamaguchi, K.; Yamaki, 598 M.; Itoh, T.; Nishigaya, T.; Nakata, R.; Morimoto, K. J. Phys. Chem. B 599 2004, 108, 2501-2508.

600 (49) Silva, A. M. S.; Alkorta, I.; Elguero, J.; Silva, V. L. M. J. Mol. 601 Struct. 2001, 595, 1-6.

602 (50) Gultepe, E.; Nagesha, D.; Sridhar, S.; Amiji, M. Adv. Drug 603 Deliver Rev. 2010, 62, 305-315.

604 (51) Anglin, E. J.; Cheng, L.; Freeman, Q. R.; Sailor, M. J. Adv. Drug 605 Deliver Rev. 2008, 60, 1266-1277.

606 (52) Vivero-Escoto, J. L.; Slowing, I. I.; Trewyn, B. G.; Lin, V. S.-Y. 607 Small 2010, 6, 1952-1967.

608 (53) Zhu, Y.; Ikoma, T.; Hanagata, N.; Kaskel, S. Small 2010, 6, 609 471-478.

610 (54) Halestrap, A. P.; Denton, R. M. Biochem. J. 1974, 138, 313-316. 